\title{
PELATIHAN PEMBUATAN AKSESORI FASHION BATIK SHIBORI MIX LIONTIN RESIN BAGI MASYARAKAT KAMPOENG HERITAGE KAJOETANGAN SEBAGAI SOUVENIR IKONIK DESA WISATA
}

\author{
Lisa Sidyawati $^{1}$, Swastika Dhesti Anggriani ${ }^{2}$, Abdul Rahman Prasetyo ${ }^{3}$ \\ ${ }^{12,3)}$ Jurusan Seni dan Desain, Fakultas Sastra, Universitas Negeri Malang, Indonesia \\ e-mail: lisa.sidyawati.fs@um.ac.id
}

\begin{abstract}
Abstrak
Menurut data situs resmi Badan Pusat Statistik (BPS) Kota Malang, wisatawan yang berkunjung ke Kota Malang tahun 2019 melonjak hingga lebih dari $100 \%$ di bandingkan tahun 2018. Wisatawan asing dan lokal yang berkunjung selalu menyusuri bangunan Heritage yang ada di Kota Malang. Diantara bangunan Heritage tersebut, terdapat sebuah kampung yang terletak di dalam sebuah gang di Jl. Jend. Basuki Rachmat Gg. IV dan VI, Kota Malang, Jawa Timur bernama Kampoeng Heritage Kajoetangan. Tercatat wisatawan yang berkunjung disana sejumlah 4000 per tahun. Pengunjung melakukan perjalanan wisata dari rumah satu ke rumah lain yang bergaya kolonial Belanda dan masih ditempati pemiliknya. Namun wisatawan kesulitan mencari souvenir khas Kampoeng Heritage Kajoetangan, seharusnya sebuah tempat wisata selain menyediakan objek wisata juga souvenir yang dapat dibeli oleh wisatawan. Fungsi souvenir tidak hanya menyimpan kenangan tentang perjalanan yang dilakukan, melainkan juga sebagai ikon dari daerah tujuan wisata sekaligus memberi andil dalam mendukung pariwisata. Pengabdi membantu masyarakat disana untuk mengoptimalkan wilayah dengan menumbuh kembangkan kemampuan berwirausaha souvenir ikonik desa wisata. Selain menghasilkan uang, souvenir juga berfungsi sebagai sarana promosi. Untuk mendukung program tersebut maka pengabdi melakukan pelatihan pembuatan aksesori fashion batik shibori mix liontin resin. Pendekatan Participatory Rural Appraisal (PRA) digunakan sebagai prosedur pengabdian kepada masyarakat.
\end{abstract}

Kata kunci: Aksesori, Shibori, Resin, Souvenir, Kampoeng Heritage

\begin{abstract}
According to data from the official website of the Central Statistics Agency (BPS) of Malang City, tourists visiting Malang City in 2019 jumped by more than $100 \%$ compared to 2018 . Foreign and local tourists who visit always visit heritage buildings in Malang City. Among the heritage buildings, there is a village located in an alley on Jl. Gen. Basuki Rachmat Gg. IV and VI, Malang City, East Java named Kampoeng Heritage Kajoetangan. Recorded tourists who visit there as many as 4000 per year. Visitors travel from house to house in the Dutch colonial style and are still occupied by the owner. However, tourists find it difficult to find souvenirs typical of Kampoeng Heritage Kajoetangan. It should be a tourist place and provide tourist objects and souvenirs that tourists can purchase. The function of souvenirs is not only to store memories of the trips made but also as icons of tourist destinations and contribute to supporting tourism. The service helps the community optimize the area by developing the entrepreneurial skills of iconic tourist village souvenirs. In addition to making money, souvenirs also serve as a means of promotion. To support the program, the devotees conducted training on making batik shibori fashion accessories mix resin pendants. The Participatory Rural Appraisal (PRA) approach is used as a community service procedure.
\end{abstract}

Keywords: Accessories, Shibori, Resin, Souvenir, Kampoeng Heritage Kajoetangan

\section{PENDAHULUAN}

Kota Malang selain terkenal dengan topengnya juga dikenal dengan bangunan heritage yang masih terjaga keasliannya. Aset tersebut yang membedakan Kota Malang dengan wilayah lain di Malang raya. Bila Kabupaten Malang terkenal dengan wisata candi dan kawasan pantainya, Kota Batu dengan wisata alamnya yang indah, maka Kota malang dikenal karena sejarahnya, dalam hal 
ini adalah bangunan heritage yang menjadi bukti sejarah perkembangan masa lalu Kota Malang pada jaman kolonial Belanda. Wisatawan lokal yang datang ke Kota Malang selalu berkunjung di kawasan Ijen dan sekitarnya untuk menikmati indahnya bangunan-bangunan Heritage.

Selain bangunan Heritage di wilayah Ijen terdapat pula bangunan heritage yang berada di wilayah Kayutangan. Keberadaan kawasan Kayutangan tidak bisa dilepaskan dari sejarah Kota Malang. Pada jaman kolonial Belanda, wilayah ini menjadi pusat perekonomian bagi Kota Malang, terutama yang berada di sekitar aloon-aloon Malang. Di kawasan ini banyak berdiri pertokoan yang selalu ramai oleh pembeli.

Kawasan Kayutangan, dulu dikenal dengan nama Jalan Pita, merupakan sebuah daerah yang terbentang mulai dari pertigaan PLN sampai ke Gereja Kayutangan. Wilayah ini dikenal dengan nama Kayutangan karena di ujung jalan arah alun-alun terdapat pohon yang menyerupai tangan. Kayutangan (Kajoetangan) banyak disebut dalam buku laporan Belanda tahun 1890 hingga masih diucapkan sampai sekarang.

Diantara bangunan-bangunan Heritage tersebut, terdapat sebuah kampung yang terletak di Jalan Jend. Basuki Rachmat Gg. IV dan Gg. VI, Kota Malang, Jawa Timur. Kampung ini termasuk desa wisata yang sering dikunjungi oleh wisatawan, baik lokal maupun mancanegara. Tercatat wisatawan yang berkunjung disana sejumlah 4 ribu per tahun. Dilihat dari keadaan tersebut, Kampoeng Heritage Kajoetangan memiliki potensi begitu besar serta strategis karena terletak di jantung Kota Malang dan sudah seharusnya wisata heritage di Kota Malang terus dipromosikan kepada khalayak umum.

Salah satu media promosi yang bisa dilakukan adalah adanya souvenir khas di kawasan wisata tersebut. Hasil wawancara pengabdi dengan para wisatawan yang datang ke Kota Malang, wisatawan lokal maupun mancanegara kesulitan untuk mendapatkan souvenir khas Kota Malang, apalagi souvenir khas Kampoeng Heritage Kajoetangan. Seharusnya sebuah tempat wisata selain menyediakan objek wisata, juga menyediakan souvenir yang dapat dibeli oleh wisatawan tersebut. Souvenir bukan hanya sarana menyimpan kenangan tentang perjalanan yang dilakukan, melainkan juga sebagai ikon dari daerah tujuan wisata, serta turut berperan dalam mendukung pariwisata. Oleh karena itu, pengabdi ingin membantu masyarakat Kampoeng Heritage Kajoetangan untuk mengoptimalkan potensi wilayah ini dengan cara membuat sebuah souvenir khas kampung wisata ini. Pengabdi akan merangkul warga untuk dapat mengembangkan kemampuan berwirausaha yang selanjutnya mampu mengangkat potensi daerah. Selain menghasilkan uang, juga dapat digunakan sebagai sarana promosi Kampoeng Heritage Kajoetangan.

Dalam pelatihan ini aksesori fashion berupa kalung, gelang, dan scraf dengan teknik shibori mix liontin resin dipilih oleh tim pengabdi untuk dijadikan souvenir karena pengabdi mempertimbangkan sasaran pengunjung yang datang ke Kampoeng Heritage Kajoetangan adalah wisatawan lokal dan asing yang memiliki jenjang usia anak-anak muda dan ibu-ibu yang sering berfoto tematik untuk dijadikan konten media sosial. Terkadang pengunjung membawa rombongan fotografer untuk melakukan pemotretan sehingga aksesori bergaya-gaya jadoel sangat diminati. Aksesori batik ini dibuat dengan menggunakan batik shibori dan berliontin resin yang didalamnya terdapat replika kecil bangunan kolonial yang berada di Kampoeng Heritage Kajoetangan. Teknik dan bahan yang pengabdi pilih juga dengan pertimbangan bahwa teknik tersebut akan mudah diikuti oleh warga, bentuknya artistik, dan sedang marak disukai oleh masyarakat sekarang (mengikuti arah fashion dan selera pasar).

Bahan baku pembuatan souvenir ini mudah didapatkan di pasar besar di sekitar wilayah Kayutangan, sehingga memudahkan jika masyarakat ingin berwirausaha souvenir ini dimasa depan. Dengan diberikannya pelatihan pembuatan souvenir ini, diharapkan produk-produk souvenir khas Kampoeng Heritage Kajoetangan tidak hanya memenuhi selera wisatawan domestik saja namun juga wisatawan asing. Harapannya pembuatan souvenir ini dalam jangka panjang akan dapat menjadi lapangan pekerjaan baru dan menjadi sarana promosi budaya Indonesia, khususnya Malang, di dunia internasional.

\section{METODE}

Tahapan Pelatihan Pembuatan Souvenir Batik Motif Bangunan Kampung Heritage Kayutangan Malang dengan Teknik Smok Sebagai Modal Kemampuan Berwirausaha Masyarakat untuk Melayani Souvenir Wisatawan Asing dapat dijabarkan sebagai berikut: 


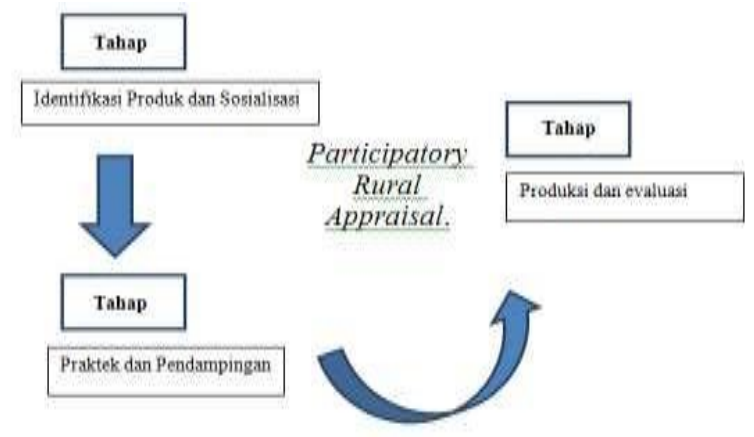

Gambar 1. Prosedur Participatory Rural Appraisal (Chambers, 1996)

Prosedur pengabdian kepada masyarakat ini menggunakan pendekatan Participatory Rural Appraisal (PRA) atau Pemahaman Partisipatif Kondisi Pedesaan. PRA adalah pendekatan dan metode yang memungkinkan masyarakat secara bersama-sama menganalisis masalah kehidupan dalam rangka merumuskan perencanaan dan kebijakan secara nyata. Pada intinya PRA adalah sekelompok pendekatan atau metode yang memungkinkan masyarakat untuk saling berbagi, meningkatkan, dan menganalisis pengetahuan mereka tentang kondisi dan kehidupan nya serta membuat rencana dan tindakan nyata (Chambers, 1996). Langkah Participatory Rural Appraisal dapat dijabarkan sebagai berikut:

\section{A. Tahap Persiapan (Identifikasi Produk dan Sosialisasi)}

1. Pada tahapan ini pengabdi melakukan observasi di Kampoeng Heritage Kajoetangan dan observasi untuk mendapatkan data mengenai bangunan heritage yang ada disana untuk mendapatkan gambaran produk souvenir yang di butuhkan dan dapat dikembangkan di wilayah ini. Pengabdi juga melakukan diskusi dengan warga Kampoeng Heritage Kajoetangan untuk mengetahui potensi kesediaan masyarakat mengembangkan wilayahnya dengan membuat wirausaha jangka panjang, yang ditindak lanjuti dengan pelatihan pembuatan souvenir aksesori fashion mix liontin resin khas Kayutangan.

2. Gambaran rencana produk juga di sosialisasikan kepada masyarakat Kampoeng Heritage Kajoetangan pada tahapan ini, setelah mendapatkan kesepakatan produk souvenir yang tersebut, maka pengabdi akan menindaklanjuti untuk pengurusan surat tugas dari kampu sekaligus surat izin resmi kepada Kepala Desa Kayutangan.

3. Langkah selanjutnya tim pengabdi melakukan persiapan materi pelatihan, membuat handout sebagai media pembelajaran, membuat contoh produk, serta mempersiapkan alat dan bahan sesuai dengan jumlah yang dibutuhkan peserta pelatihan, membuat lembar observasi, angket untuk respon peserta pelatihan.

\section{B. Tahap Pelaksanaan (Praktek dan Pendampingan)}

Tahapan praktek dan pendampingan ini merupakan tahapan proses pembuatan aksesori fahion batik Shibori Mix Liontin Resin bagi Masyarakat Khas Kampoeng Heritage Kajoetangan sebagai souvenir ikonik desa wisata dari langkah per langkah. Tim pengabdi mendampingi pada setiap langkah pembuatan serta memberikan masukan dan konsultatif jika ada peserta yang belum berhasil menguasai ketrampilan pada setiap langkahnya.

\section{Tahap Monitoring dan Evaluasi}

1. Tahap monitoring pada pelatihan ini yaitu kegiatan mengamati perkembangan ketrampilan peserta dengan diskusi dan observasi, kegiatan ini bertujuan untuk mengetahui seberapa besar peningkatan kemampuan dalam membuat produksi souvenir aksesori fashion khas Kampoeng Heritage Kajoetangan dilihat dari segi kuantitatif (banyaknya produksi yang dihasilkan dalam selang waktu tertentu) dan kualitatif (inovasi yang dihasilkan, dapat berupa pembuatan inovasi motif dan warna).

2. Tahap Evaluasi yaitu kegiatan refleksi terhadap kesulitan dan potensi dalam proses pembuatan produk sehingga ditemukan solusi yang bisa meningkatkan produksi. 


\section{HASIL DAN PEMBAHASAN}

\section{A. Hasil Tahap Persiapan}

Pada tahap persiapan tim pengabdian mengadakan pertemuan untuk mendiskusikan alur kegiatan yang akan dilaksanakan, tim membuat undangan kepada warga Kampoeng Heritage Kajoetangan. Peserta yang mendaftar mengikuti kegiatan ini sejumlah 25 orang. Setelah terdata peserta yang ingin mengikuti kegiatan pelatihan, tim pengabdian mendiskusikan detail jadwal kegiatan pelatihan yang tentunya disesuikan dengan bagian sarana prasaranan untuk meminta ijin penggunaan lokasi pelatihan.

\section{B. Hasil Tahap Pelaksanaan}

\section{1) Penyampaian Materi Batik Ikat}

Tim pengabdian menyampaikan materi mengenai batik ikat. Materi batik meliputi ragam hias serta proses pembuatan batik yang nantinya akan digunakan sebagai motif yang diplikasikan diatas kain. Peserta diberikan kesempatan untuk mencatat serta bertanya terhadap materi yang disampaikan oleh narasumber. Selama proses penyampaian materi peserta sangat berantusias sehingga terdapat banyak pertanyaan yang disampakan ketika peserta belum memahami suatu hal yang disampaikan oleh pemateri. Suasana penyampaian materi dapat dilihat dengan dokumentasi sebagai berikut:

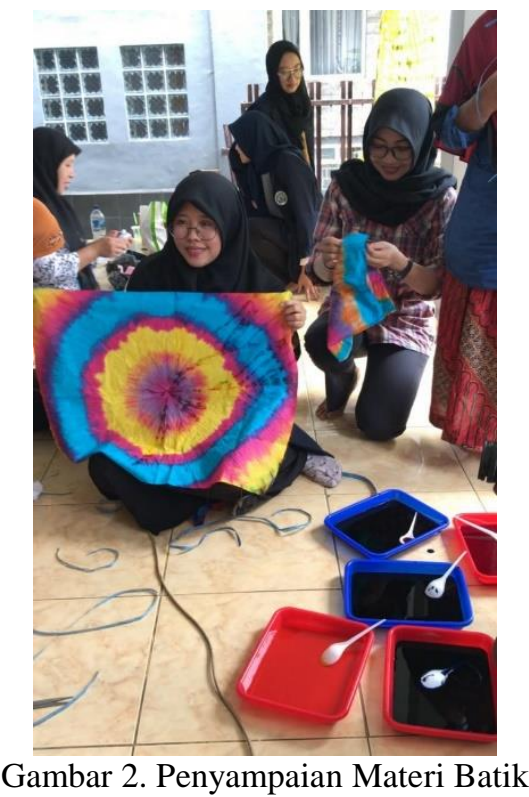

\section{2) Proses Pengikatan dan Pewarnaan Karya}

Pada tahapan ini peserta membentuk kelompok kerja dimana setiap kelompok berjumlah 4 orang, peserta memiliki job desk masing-masing yaitu ada yang mendesain motif batik pada kain dan ada yang mengikat. Peserta bisa mengikat dengan alat dan bahan yang disediakan oleh panitia, antara lain kelereng, batu, talia rafia serta cetakan-cetakan pola yang lain. Pemateri dan tim pengabdian berkeliling untuk mengarahkan ketepatan peserta dalam membuat desain motif batik serta ketepatan dalam mengikat pada kain. Setelah melakukan proses pengikatan terhadap kain yang sesuai dengan desain yang dibuat, peserta mewarnai kain tersebut sesuai dengan warna yang diinginkan. Pengabdi menyediakan dua warna yaitu merah, biru dah hitam, peserta bisa memilih salah satu warna tersebut atau memakai dua duanya. Suasana mengikat pada kain dapat dilihat dengan dokumentasi sebagai berikut: 


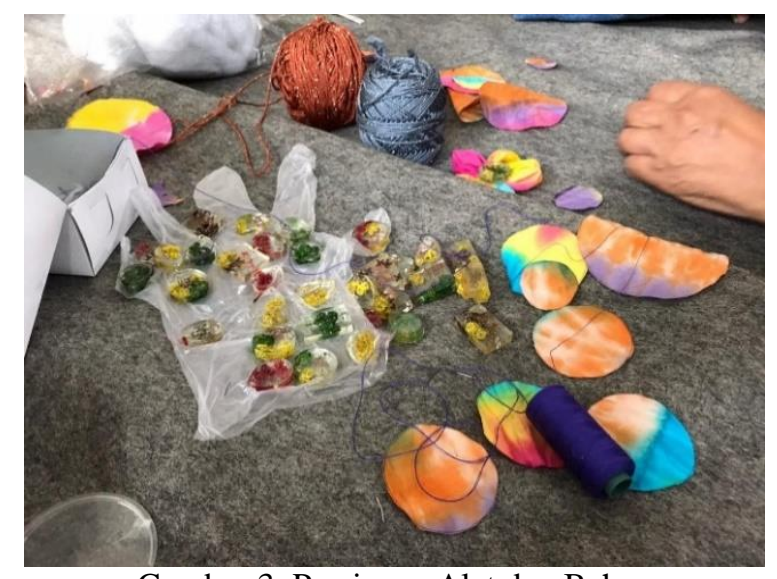

Gambar 3. Persiapan Alat dan Bahan

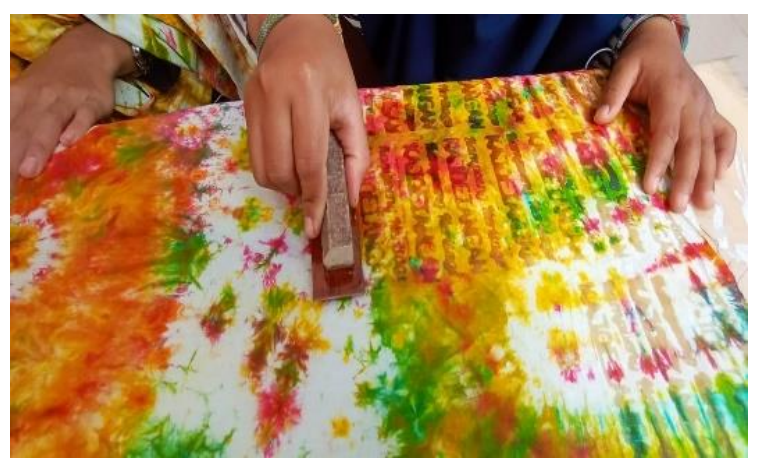

Gambar 4. Pembuatan Motif Batik

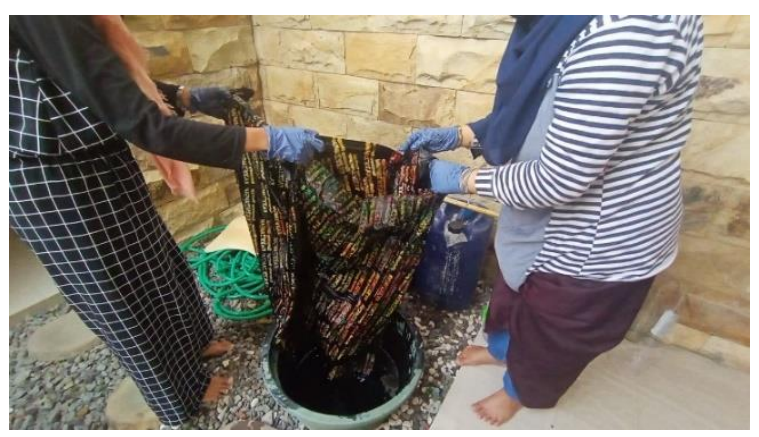

Gambar 5. Pewarnaan

\section{3) Proses Pembuatan Liontin Resin}

Pada tahapan ini, peserta membuat adonan untuk lapisan pertama, lalu menuangkan resin bening ke wadah cetakan. Setelah itu peserta menambahkan beberapa tetes pengeras resin. Peserta mengaduk dan mencampur sampai rata, setelah diaduk peserta menunggu sampai gelembung udaranya hilang. Setelah beberapa menit sampai campuran menjadi gel. Peserta membuat campuran baru yang sama untuk lapisan kedua, lalu menyiapkan bahan untuk isian yaitu gambar ikon Kampoeng Heritage Kajoetangan. Untuk memasukkan isian maka seluruh bagian harus dilumuri dengan resin dan katalis. Peserta menunggu sampai resin mengeras di semua lapisan, lalu liontin siap dikeluarkan dari cetakan. 
Gambar 6. Pembuatan Liontin dengan Bahan Resin

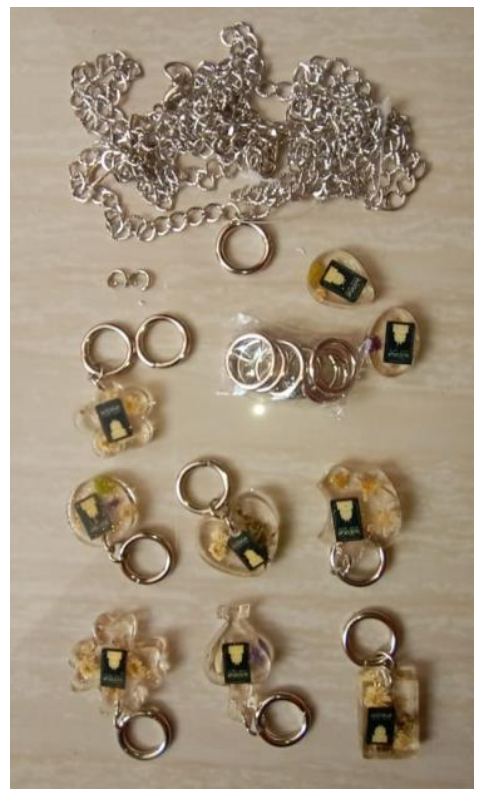

Gambar 7. Perangkaian Liontin

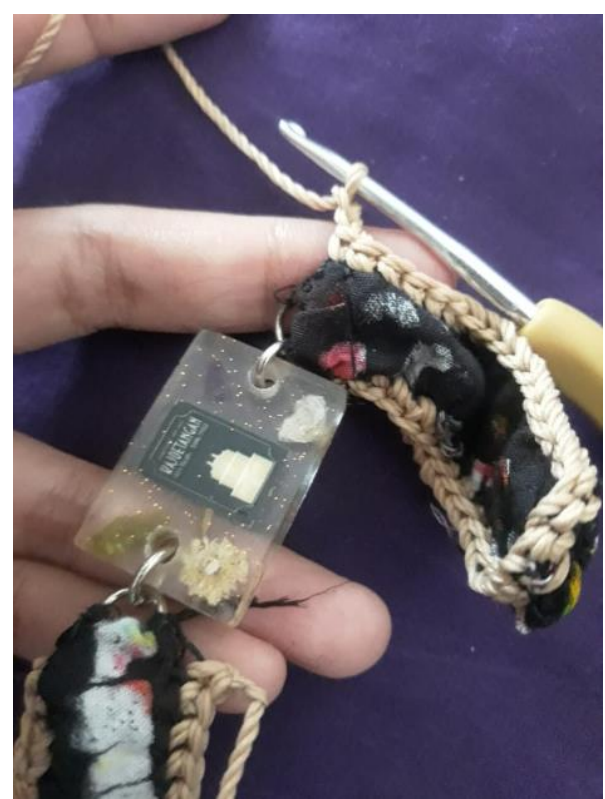

Gambar 8. Merangkai Liontin dengan Kain Shibori 


\section{4) Produk Hasil Pelatihan} berikut:

Hasil akhir dari pelatihan souvenir khas Kampoeng Heritage Kajoetangan adalah sebagai

a. Gelang batik ikat mix liontin resin

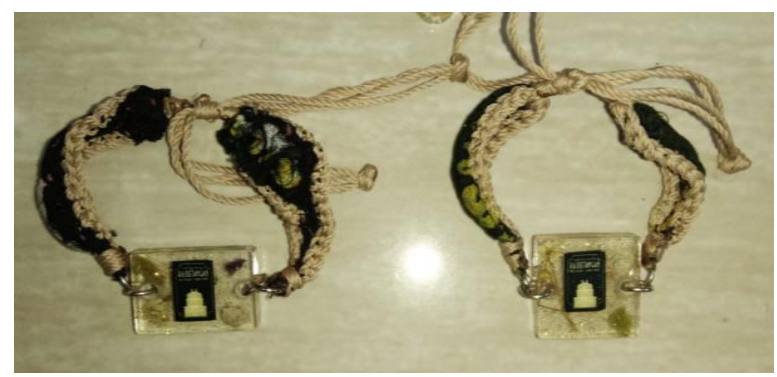

Gambar 9. Gelang Ikat Mix Liontin

b. Gantungan tas batik ikat mix liontin resin

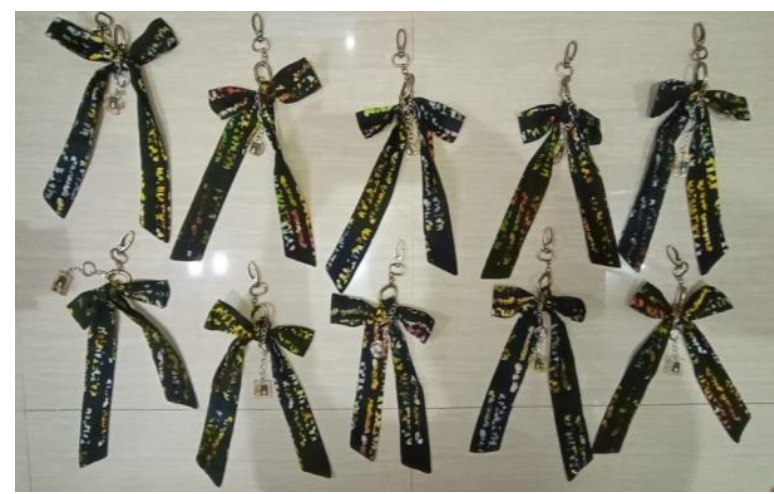

Gambar 10. Gantungan Tas Mix Liontin

c. Kalung Batik Ikat Mix Liontin Resin

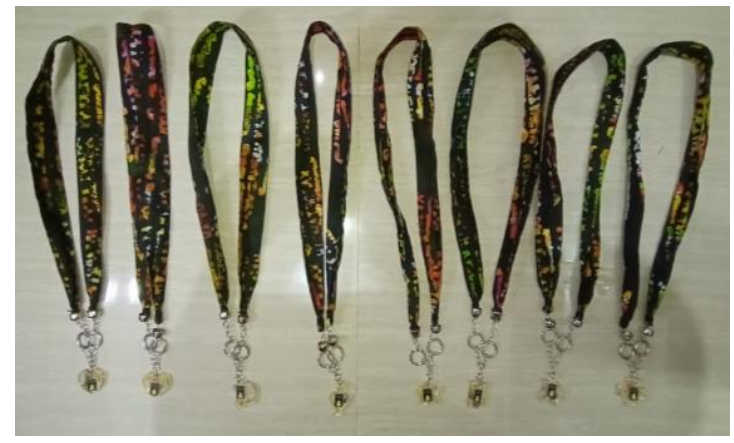

Gambar 11. Kalung Mix Liontin

\section{Hasil Pelatihan Pembuatan Aksesori Fashion Batik Shibori Mix Liontin Resin}

Hal yang diharapkan dari sebuah program adalah tingkat keberhasilan dari program tersebut. Keberhasilan suatu program dapat dilihat dari proses dan hasil yang didapatkan setelah program berlangsung. Adapun pembahasan keberhasilan dalam sebuah kegiatan tertentu dapat diukur melalui evaluasi program yang dijalankan, evaluasi proses kegiatan, dan evaluasi hasil. Dalam pelaksanaan program pelatihan di Kampoeng Heritage Kajoetangan terdapat beberapa hal sebagai berikut:

\section{1) Keaktifan}

Aktifitas para peserta telah menunjukkan kesungguhan dan antusiasisme dalam mengikuti pelatihan. Hal ini dapat dilihat dari kegiatan tanya jawab saat pemateri menyampaikan materinya, 
juga tanya jawab pada saat proses prakter berlangsung, serta keaktifan kedatangan saat pelaksanaan pelatihan. Serta pada saat penyelesaian karya semuanya tepat waktu tidak ada yang menunda pengumpulan karya.

\section{2) Keterampilan}

Untuk mengetahui seberapa tingkat ketrampilan para peserta pelatihan maka dilakukan pengamatan (observasi) dan tim pengabdian melakukan pendekatan terutama bagi peserta yang ketrampilannya redah. Tolak ukur tingkat ketrampilan dalam pelatihan ini adalah meliputi ketepatan teknik dalam membuat desain motif, mengikat pola-pola pada mukena, pewarnaan batik dan finishing sedangkan sebagian besar peserta sudah menggunakan prinsip seni rupa dalam mengerjakan produknya. Hasilnya ketrampilan peserta dalam membuat desain motif, mengikat pola-pola pada mukena, pewarnaan batik dan finishing sudah sesuai dengan teori yang ada dan tidak ada yang menyimpang baik isi maupun konsepnya.

\section{3) Tahap Pelaporan}

Setelah pelaksanaan pelatihan, tingkat keahlian peserta pelatihan berbeda-beda. Disini terdapat dua tingkatan yang sudah mahir dan sedang. Para peserta pelatihan yang memiliki kemampuan sedang walaupum ikut juga dalam pelatihan dianjurkan belajar pada teman yang memiliki tingkat kemahiran yang tinggi. Pada tahap ini, sebelum melakukan pelaporan, tim pengabdian melakukan observasi lagi kepada para peserta pelatihan. Ini dilakukan untuk mengetahui tingkat keberhasilan pelatihan yang dilaksanakan secara intensif selama dua hari dan menjaring data berkisar tanggapan para peserta tentang pelatihan ini. Setelah data terkumpul, kami menyusun laporan terdiri dari laporan tertulis disertai dengan hasil produk mukena batik jumputan yang telah dihasilkan oleh peserta pelatihan.

Keberhasilan kegiatan ini dapat diukur dari beberapa indikator diantaranya adalah:

a. Kemampuan mengumpulkan ide-ide membuat desain dan pola motif serta ide dalam pembuatan warna

b. Kemampuan dalam mengolah ide dan mengaplikasikannya dalam asesoris batik ikat mix liontin resin

Hasil akhir berupa produk kalung, gelang dan gantungan tas yang sudah mendekati keberhasilan. Namun demikian masih perlu penyempurnaan dalam hal desain motif batik yang bervariasi lagi serta teknik mengikat dan mewarna. Para peserta pelatihan telah berupaya membuat batik sebaik mungkin, beberapa kekurangan kecil perlu dimaklumi mengingat mereka belum pernah mendapatkan pengetahuan maupun pelatihan semacam ini sebelumnya.

\section{SIMPULAN}

Masyarakat Kampoeng Heritage Kajoetangan ini banyak yang memiliki usaha rumahan sehingga secara ekonomi mereka sudah terbiasa memproduksi barang yang nantinya akan dijual lagi kepada suplayer kedua. Secara letak, sebenarnya kampung ini sangat strategis, berada di jantung Kota Malang. Dengan kestrategisan tersebut seharusnya warga tidak hanya memproduksi barang saja, tetapi mampu menjualnya sendiri melalalui outlet-outlet disekitarnya. Selain itu barang yang di produksi bukan hanya makanan saja, melainkan juga barang kerajinan yang mempunyai nilai ekonomis tinggi sehingga mampu menguasai pasar.

Diadakannya pelatihan ini berhasil membuat produk-produk asesoris yang inovatif dan layak jual. Keberhasilan kegiatan ini dapat diukur dari beberapa indikator diantaranya: (1) Kemampuan peserta dalam membuat motif dan pola yang bervariatif; (2) Kemampuan peserta pelatihan dalam membuat ikatan pola; (3) Kemampuan peserta pelatihan dalam memberikan warna pada motif dan melakukan finishing; (4) Kemampuan peserta dalam membuat liontin resin.

Kegiatan ini memiliki dampak positif bagi peserta pelatihan yaitu masyarakat Kampoeng Heritage Kajoetangan, karena produknya dapat dijadikan produk layak jual. Para peserta pelatihan nampaknya juga baru pertama kali mendapatkan pelatihan seperti ini sehingga begitu antusias dalam mengikuti semua proses pembuatan souvenir ini. 


\section{UCAPAN TERIMA KASIH}

Ucapan terima kasih kami sampaikan kepada:

a. Rektor Universitas Negeri Malang atas izin dan pembinaannya sehingga kegiatan Tri Dharma Perguruan Tinggi ini terlaksana dengan baik.

b. Ketua Lembaga Penelitian dan Pengabdian kepada Masyarakat (LP2M) Universitas Negeri Malang atas dukungan dan arahannya.

c. Mitra Kampoeng Heritage Kajoetangan atas partisipasi dan kerjasamanya.

d. Seluruh anggota tim pelaksana kegiatan pelatihan atas kerjasamanya yang baik.

e. Seluruh pihak yang telah berpartisipasi dalam kegiatan pelatihan ini yang tidak dapat kami sebutkan satu persatu.

\section{DAFTAR PUSTAKA}

Chambers, R., \& Sukoco, Y. (1996). PRA: PARTICIPATORY RURAL APPRAISAL, Memahami Desa Secara Partisipatif. Kanisius.

Khakim, M. N. L., Putri, M. U. U., Suktianto, W., \& Budi, N. A. (2019). Urgensi Pengelolaan Pariwisata Kampung Heritage Kajoetangan Malang. Jurnal Teori Dan Praksis Pembelajaran IPS, 4(1), 15-22. https://doi.org/10.17977/um022v4i12019p015

Kurniasih, N. (2016). Infografis. Komunikasi, Informasi, Dan Perpustakaan Di Era Global, 456465. https://doi.org/10.13140/RG.2.2.27145.03680

Rochdyanto, S. (2000). Langkah-langkah Pelaksanaan Metode PRA. In Makalah ToT PKPI. Yogyakarta.

Simanjuntak, B. A., Tanjung, F., \& Nasution, R. (2017). Sejarah Pariwisata: Menuju Perkembangan Pariwisata Indonesia. Yayasan Pustaka Obor Indonesia.

Herlina, Sri. (2009). Batik. Malang: Indah Offset.

Susanto, M. (2012). DIKSI RUPA, Kumpulan Istilah dan Gerakan Seni Rupa. Yogyakarta: DictiArt. 